\title{
Inhibitors of Aminoglycoside Resistance Activated in Cells
}

\author{
Kenward Vong, Ingrid S. Tam, Xuxu Yan, and Karine Auclair* \\ Department of Chemistry, McGill University, 801 Sherbrooke Street West, Montréal, Québec, Canada H3A 2K6
}

\section{Supporting Information}

ABSTRACT: The most common mechanism of resistance to aminoglycoside antibiotics entails bacterial expression of drugmetabolizing enzymes, such as the clinically widespread aminoglycoside $N$-6'-acetyltransferase $\left(\mathrm{AAC}\left(6^{\prime}\right)\right)$. Aminoglycoside-CoA bisubstrates are highly potent $\mathrm{AAC}\left(6^{\prime}\right)$ inhibitors; however, their inability to penetrate cells precludes in vivo studies. Some truncated bisubstrates are known to cross cell membranes, yet their activities against $\mathrm{AAC}\left(6^{\prime}\right)$ are in the micromolar range at best. We report here the synthesis and biological activity of aminoglycoside-pantetheine derivatives that, although devoid of $\mathrm{AAC}\left(6^{\prime}\right)$ inhibitory activity, can potentiate the antibacterial activity of kanamycin A against an aminoglycoside-

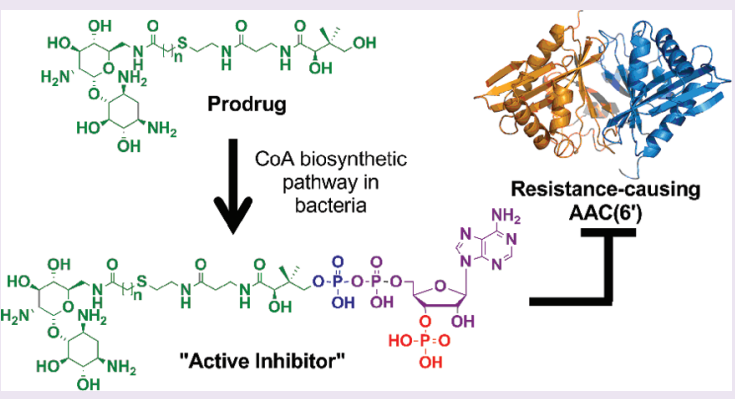
resistant strain of Enterococcus faecium. Biological studies demonstrate that these molecules are potentially extended to their corresponding full-length bisubstrates by enzymes of the coenzyme A biosynthetic pathway. This work provides a proof-ofconcept for the utility of prodrug compounds activated by enzymes of the coenzyme A biosynthetic pathway, to resensitize resistant strains of bacteria to aminoglycoside antibiotics.

$\mathrm{T}$ he World Health Organization (WHO) has recently classified antibiotic resistance as one of the three greatest threats to human health. Among antibacterial agents, aminoglycosides occupy a special niche due to their effectiveness against aerobic, Gram-negative, and Gram-positive bacteria. ${ }^{1,2}$ Inevitably, however, their clinical use has been compromised by the rapid emergence of bacterial resistance. ${ }^{3}$ The most common mechanism of resistance to aminoglycosides entails bacterial expression of drug-metabolizing enzymes, such as the clinically widespread aminoglycoside N-6'-acetyltransferase (AAC$\left.\left(6^{\prime}\right)\right) .^{4-6}$ Using acetyl coenzyme A (AcCoA), AAC $\left(6^{\prime}\right)$ acetylates the $6^{\prime}$-amino group of aminoglycosides.

Previous work in our group focused on aminoglycoside-CoA bisubstrate inhibitors of $\mathrm{AAC}\left(6^{\prime}\right) .^{7-9}$ Many of these were nanomolar inhibitors, such as $\mathbf{2 a - c}$ (Figure 1, panel a), and also proved to be useful structural probes for different AAC $\left(6^{\prime}\right)$ isoforms. ${ }^{7,10}$ Due to their negatively charged phosphate groups, however, these bisubstrate inhibitors were not expected to permeate cellular membranes. We subsequently reported truncated derivatives able to penetrate bacterial cells. ${ }^{11}$ One of these inhibitors, compound 1, was the first molecule shown to block aminoglycoside resistance in cells. Its potency, however, was greatly lower $\left(K_{\mathrm{i}}=11 \mu \mathrm{M}\right)$ than that of its corresponding bisubstrate $\left(K_{\mathrm{i}}=0.076 \mu \mathrm{M}\right)$. With the aim of generating more potent cell-permeable $\mathrm{AAC}\left(6^{\prime}\right)$ inhibitors, we designed molecules that would be extended into bisubstrates once inside bacterial cells. We report here the synthesis and biological studies of compounds $3 \mathbf{a}-\mathbf{e}$ (Figure 1, panel a) that have no $\mathrm{AAC}\left(6^{\prime}\right)$ inhibitory activity of their own yet have the ability to block aminoglycoside resistance in cells. We also report evidence to support activation of $3 \mathbf{a}-\mathbf{e}$ to $2 \mathrm{a}-\mathrm{e}$ in vivo by enzymes of the coenzyme A ( $\mathrm{CoA}$ ) biosynthetic pathway.
Results and Discussion. Design. CoA is an essential cofactor in many biological processes, most notably in the synthesis and oxidation of fatty acids. ${ }^{12}$ In almost all prokaryotes and eukaryotes, the common precursor to CoA is pantothenic acid, which is obtained either through de novo biosynthesis or from active transport from the environment. ${ }^{13,14}$ Bacteria are also known to actively import exogenous amounts of pantetheine for transformation into $\mathrm{CoA} .^{15}$ This biosynthetic system has been shown to transform pantothenamides $^{16}$ and other derivatives for use in protein labeling. ${ }^{17,18}$ Because of its promiscuity, we envisaged to take advantage of the CoA biosynthetic pathway to generate the potent AAC $\left(6^{\prime}\right)$ inhibitors $\mathbf{2} \mathbf{a}-\mathbf{e}$ in cells. Compounds $\mathbf{3 a}-\mathbf{e}$ were designed to be membrane-permeable substrates of the CoA biosynthetic enzymes (Figure 2). Activation of $3 a-e$ to the bisubstrate inhibitors $2 \mathbf{a}-\mathbf{e}$ was expected to proceed via the action of pantothenate kinase (PanK), ${ }^{19}$ phosphopantetheine adenylyltransferase (PPAT), ${ }^{20}$ and dephosphocoenzyme A kinase (DPCK). ${ }^{21}$ Based on their known AAC $\left(6^{\prime}\right)$ inhibitory activity, ${ }^{7}$ compounds $2 \mathbf{a}-\mathbf{e}$ produced in vivo would then be expected to block aminoglycoside resistance caused by this enzyme. This is an unexplored approach to generate molecules that resensitize bacteria to aminoglycoside antibiotics.

Synthesis. The synthesis and biological activity of compounds $\mathbf{2 a - d}$ were previously reported. ${ }^{7}$ An additional bisubstrate containing a longer linker, compound $\mathbf{2 e}$, was synthesized here (see Supporting Information). Target compounds $3 a-e$ were prepared in 2 steps (Figure 1, panel

Received: September 14, 2011

Accepted: January 4, 2012

Published: January 4, 2012 


\section{a}

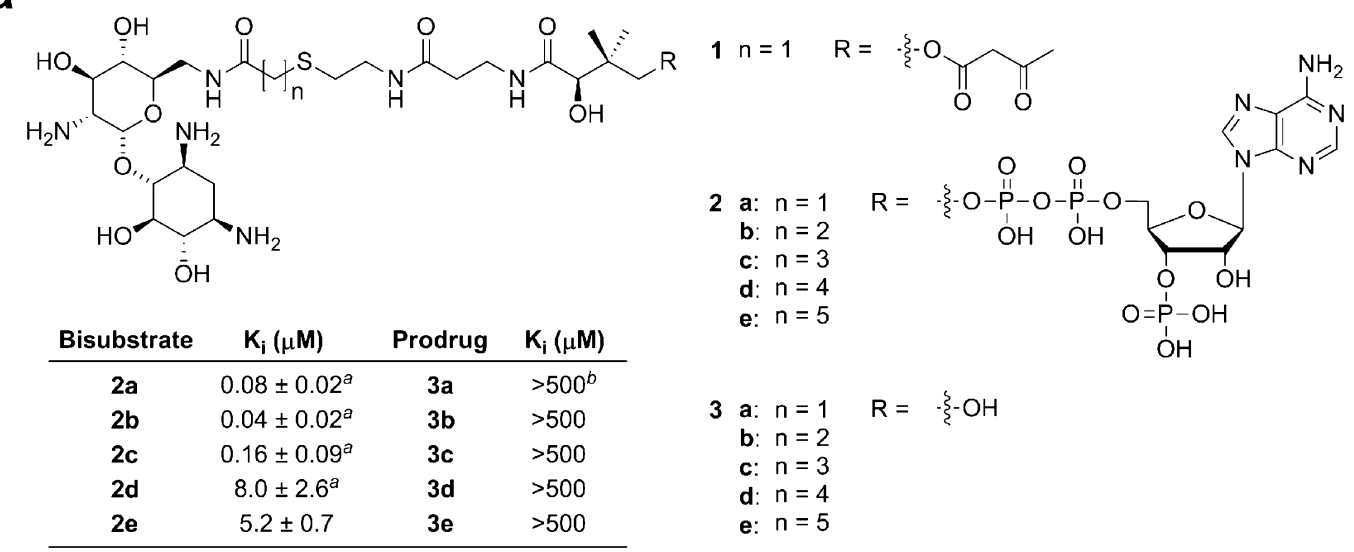

${ }^{a}$ From reference [7]. ${ }^{b}$ From reference [11].

b

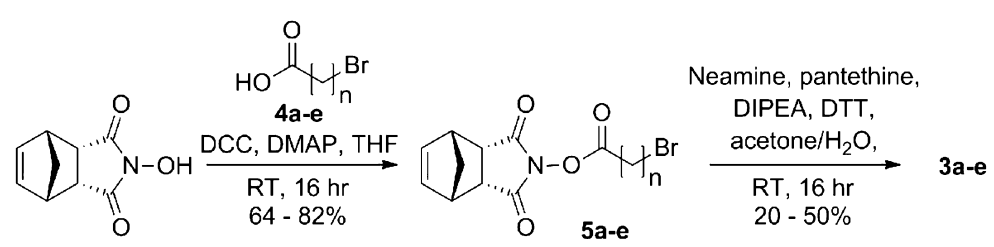

Figure 1. Structure, synthesis, and $\mathrm{AAC}\left(6^{\prime}\right)$ inhibition constants of the compounds discussed. (a) Structure of compounds $\mathbf{1}, \mathbf{2 a}-\mathbf{e}$, and $\mathbf{3 a}-\mathbf{e}$ as well as the AAC $\left(6^{\prime}\right)$-Ii inhibition constants $\left(K_{\mathrm{i}}\right)$ for $\mathbf{2 a}-\mathbf{e}$ and $\mathbf{3 a}-\mathbf{e}$. (b) Synthetic scheme used to generate compounds $\mathbf{3 a}-\mathbf{e}$. Abbreviations used: DCC, 1,3-dicyclohexylcarbodimide; DIPEA (Hunig's base), N,N-diisopropylethylamine; DMAP, N,N-dimethyl-4-aminopyridine; DTT, 1,4-dithiothreitol; THF, tetrahydrofuran; RT, room temperature.

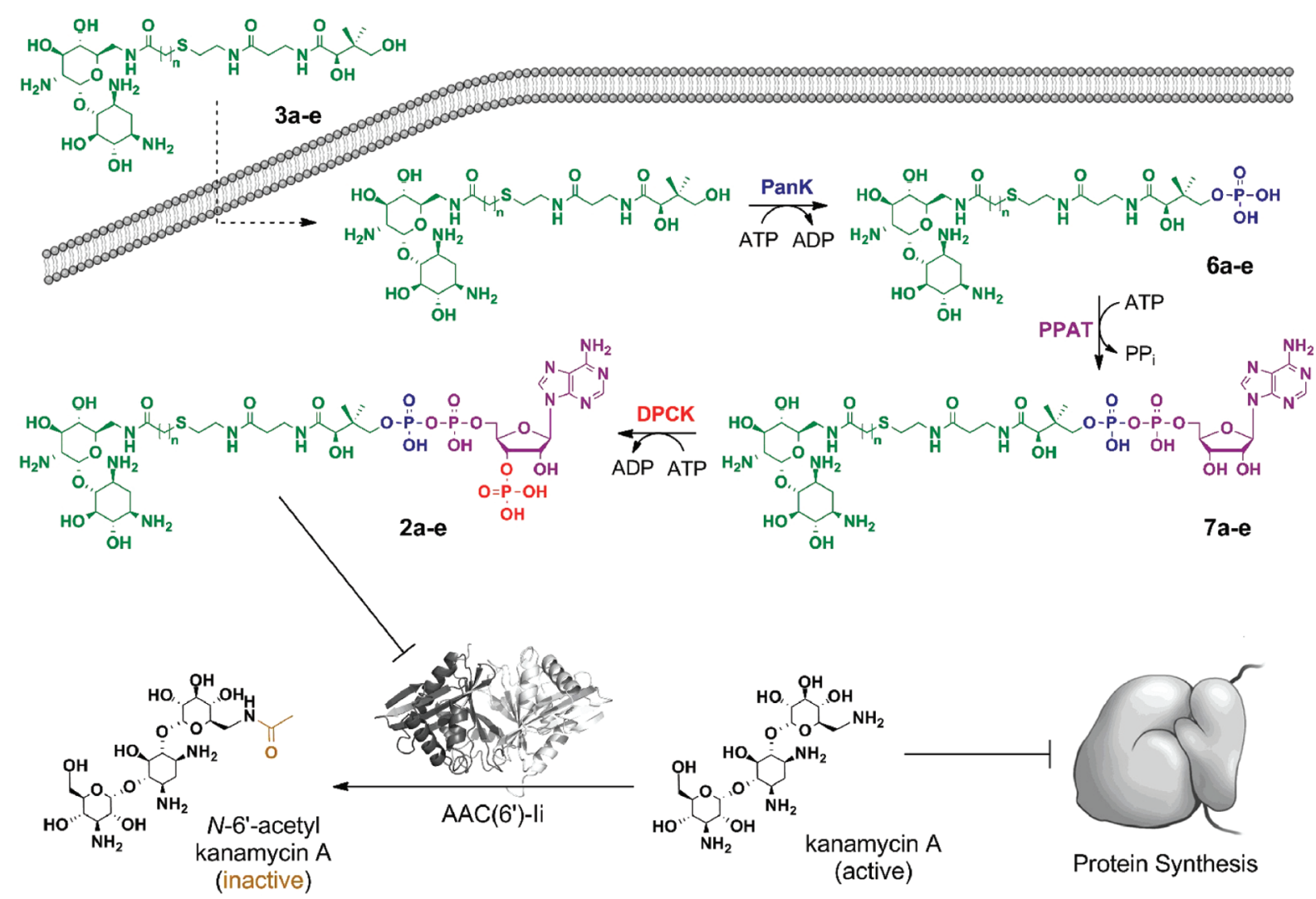

Figure 2. Proposed mechanism for the activation of $3 a-e$ to $2 a-e$ and the potentiation effect of $2 a-e$ on the activity of kanamycin A against resistant E. faecium. Following cell membrane penetration, $3 \mathbf{a}-\mathbf{e}$ are expected to undergo phosphorylation by PanK to produce $6 \mathbf{a}-\mathbf{e}$, followed by PPAT-catalyzed adenylylation to $\mathbf{7 a}-\mathbf{e}$ and phosphorylation by DPCK to generate $\mathbf{2 a}-\mathbf{e}$. Compounds $\mathbf{2 a}-\mathbf{e}$ are known inhibitors of AAC $\left(6^{\prime}\right)$-Ii. The inactivation of this resistance-causing enzyme allows aminoglycosides such as kanamycin A to disrupt protein synthesis and cause cell death. 
a

\begin{tabular}{cccc} 
Compound & $\begin{array}{c}\boldsymbol{K}_{\mathbf{m}} \\
(\boldsymbol{\mu M})\end{array}$ & $\begin{array}{c}\boldsymbol{k}_{\text {cat }} \\
\left(\mathrm{sec}^{-1}\right)\end{array}$ & $\begin{array}{c}\boldsymbol{k}_{\text {cat }} / \boldsymbol{K}_{\mathbf{m}} \\
\left(\mathbf{m M}^{-1} \mathbf{s e c}^{-1}\right)\end{array}$ \\
\hline $\begin{array}{c}\text { Pantothenic } \\
\text { acid }\end{array}$ & $17 \pm 2^{a}$ & $1.07 \pm 0.04^{a}$ & $64.2 \pm 8.1$ \\
$\begin{array}{c}\text { Pantetheine } \\
\text { 3a }\end{array}$ & $91 \pm 10^{b}$ & $0.32 \pm 0.02^{b}$ & $3.5 \pm 0.4$ \\
3b & $480 \pm 160$ & $0.47 \pm 0.05$ & $1.0 \pm 0.3$ \\
3c & $350 \pm 80$ & $0.50 \pm 0.05$ & $1.4 \pm 0.4$ \\
3d & $230 \pm 69$ & $0.52 \pm 0.08$ & $2.3 \pm 0.8$ \\
3e & $170 \pm 50$ & $0.66 \pm 0.08$ & $3.9 \pm 1.2$ \\
\hline
\end{tabular}

${ }^{a}$ From reference [16]. ${ }^{b}$ From reference [28]

b

\begin{tabular}{ccccc} 
& \multicolumn{4}{c}{ Compounds detected by LC-MS } \\
\cline { 2 - 5 } Substrate & 3a-e & 6a-e & 7a-e & 2a-e \\
\hline 3a & $70 \%$ & $5 \%$ & $25 \%$ & \\
3b & & $20 \%$ & $70 \%$ & $10 \%$ \\
3c & & $5 \%$ & $40 \%$ & $55 \%$ \\
3d & & & $10 \%$ & $90 \%$ \\
3e & & & $20 \%$ & $80 \%$ \\
\hline
\end{tabular}

${ }^{a}$ All data points are from the average of duplicate experiments.

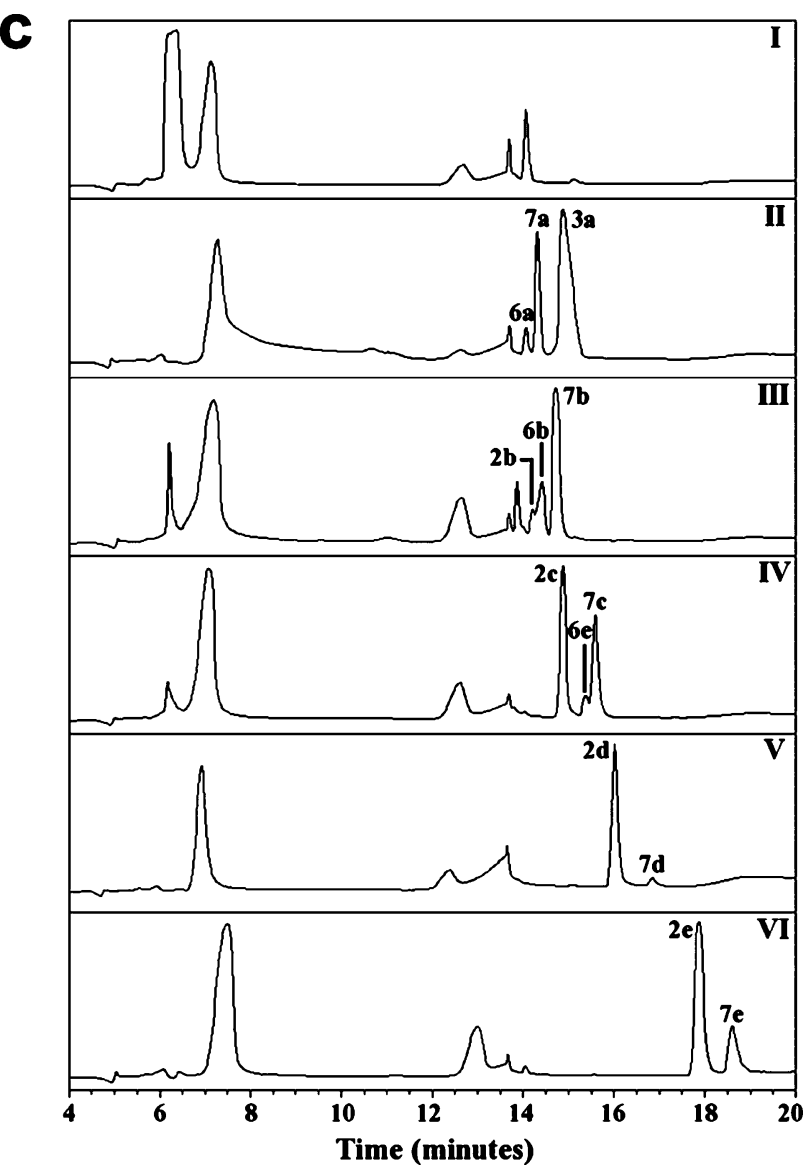

Figure 3. Transformation of $3 \mathrm{a}-\mathbf{e}$ by the CoA biosynthetic enzymes. (a) Michaelis-Menten constants $\left(K_{\mathrm{m}}\right)$, turnover rates $\left(k_{\text {cat }}\right)$ and catalytic efficiencies $\left(k_{\mathrm{cat}} / K_{\mathrm{m}}\right)$ calculated for the transformation of compounds $3 \mathrm{a}-\mathbf{e}$ by PanK. (b) Approximate ratio of starting material and the different products (expressed as a relative percentage $\pm 5 \%$ ) measured by HPLC for the in vitro transformation of $3 a-e$ by a combination of PanK, PPAT and DPCK. (c) HPLC chromatograms evaluating the in vitro biosynthetic transformation of compounds $\mathbf{3 a}-\mathbf{e}$ by a combination of PanK, PPAT, and DPCK. Reaction mixtures were incubated with (I) water, (II) 3a, (III) 3b, (IV) 3c, (V) 3d, and (VI) $3 \mathbf{e}$.

b). This pathway was adapted from a methodology reported by us. ${ }^{11}$ All final compounds were purified twice by HPLC to ensure purity ( $>95 \%)$, and the low yields reported reflect losses due to extensive sample manipulation.

Biological Studies. Figure 1 summarizes the AAC $\left(6^{\prime}\right)$-Ii inhibition constants of $\mathbf{2 a}-\mathbf{e}$. This $\mathrm{AAC}\left(6^{\prime}\right)$ isoform was selected because it is naturally expressed in Enterococcus faecium, one of the leading causes of hospital-acquired infections. ${ }^{22}$ In general, the shorter the linker, the more potent is the inhibitor. As expected from the lack of inhibition previously reported for $3 \mathrm{a}^{11}$ none of $3 \mathrm{a}-\mathrm{e}$ (tested up to $500 \mu \mathrm{M}$ ) show inhibitory activity against purified $\mathrm{AAC}\left(6^{\prime}\right)$-Ii. To investigate the potential of compounds $3 \mathbf{a}-\mathbf{e}$ to be extended to $\mathbf{2 a}-\mathbf{e}$ by the CoA biosynthetic enzymes in cells, kinetic studies were performed with purified PanK, the rate-limiting enzyme of this pathway, ${ }^{23}$ and the Michaelis-Menten constants $\left(K_{\mathrm{m}}\right)$, turnover rates $\left(k_{\text {cat }}\right)$, and catalytic efficiencies $\left(k_{\text {cat }} / K_{\mathrm{m}}\right)$ for the PanK transformation of $\mathbf{3 a}-\mathbf{e}$ were determined (Figure 3, panel a). The observed trend shows a correlation between the linker length and catalytic efficiency. Derivatives with longer linkers are generally better PanK substrates, whereas those with shorter linkers are poorer substrates (as judged from $k_{\mathrm{cat}} / K_{\mathrm{m}}$ ). Although none are as good as the natural substrate pantothenic acid, $\mathbf{3 d}$ and $\mathbf{3 e}$ are comparable to the alternative substrate, pantetheine.
A biosynthetic in vitro assay was designed to determine the potential of compounds $3 \mathrm{a}-\mathrm{e}$ to be fully extended to compounds $2 \mathrm{a}-\mathbf{e}$ by the enzymes PanK, PPAT, and DPCK. LC-MS analysis of the reaction mixtures was used to monitor the transformation of $\mathbf{3 a}-\mathbf{e}$ by these 3 enzymes in one-pot (Figure 3, panel $\mathrm{b}$ and $\mathrm{c}$ ). A product of a mass corresponding to $2 \mathbf{a}-\mathbf{e}$ is clearly observed for all but the reaction of $3 \mathbf{a}$. Moreover, the biosynthetic intermediates $6 \mathbf{a}-\mathbf{c}$ and $7 \mathrm{a}-\mathrm{e}$ are also identified. The absence of detectable $\mathbf{6 d}$ and $6 \mathrm{e}$ (Figure 3, panel c, V and VI) is attributed to a more complete transformation of $3 \mathbf{d}$ and $3 \mathbf{e}$ to $\mathbf{2 d}$ and $2 \mathbf{e}$, respectively. The approximate percent conversions of $3 \mathbf{a}-\mathbf{e}$ to $2 \mathbf{a}-\mathbf{e}, \mathbf{6} \mathbf{a}-\mathbf{e}$, and $7 \mathbf{a}-\mathbf{e}$ observed (Figure 3, panel b) are consistent with an increased efficiency of these enzymes with increasing chain length up to $n=4$. Overall, these results suggest that $3 \mathbf{b}-\mathbf{e}$ may be extended by bacteria to the full bisubstrates $\mathbf{2} \mathbf{b}-\mathbf{e}$, which may in turn inhibit AAC $\left(6^{\prime}\right)$ and block resistance.

These in vitro results encouraged us to test $3 \mathbf{a}-\mathbf{e}$ in cells. As mentioned above, E. faecium, chromosomally encoded with $\mathrm{AAC}\left(6^{\prime}\right)-\mathrm{Ii}$, is one of the leading causes of hospital-acquired infections. ${ }^{22}$ Using a standard checkerboard assay, the ability of 3a-e to resensitize E. faecium ATCC 19434 to the aminoglycoside kanamycin A was investigated. Intrinsically, compounds $3 \mathbf{a}-\mathbf{e}$ were found to lack any antibacterial activity against E. faecium. This was also the case when tested against Staphylococcus aureus ATCC 29213 and 43300, Acinetobacter 
baumannii ATCC 19606, Pseudomonas aeruginosa ATCC 27853, Klebsiella penumoniae ATCC 13883, and Escherichia coli ATCC 25922 and 11775 (data not shown). In the absence of compounds $3 \mathbf{a}-\mathbf{e}$, the minimum concentration of kanamycin A causing a $50 \%$ growth inhibition $\left(\mathrm{MIC}_{50}\right)$ of E. faecium is $\sim 125 \mu \mathrm{g} \mathrm{mL}^{-1}$ (Figure 4, panel a). As expected from the in vitro
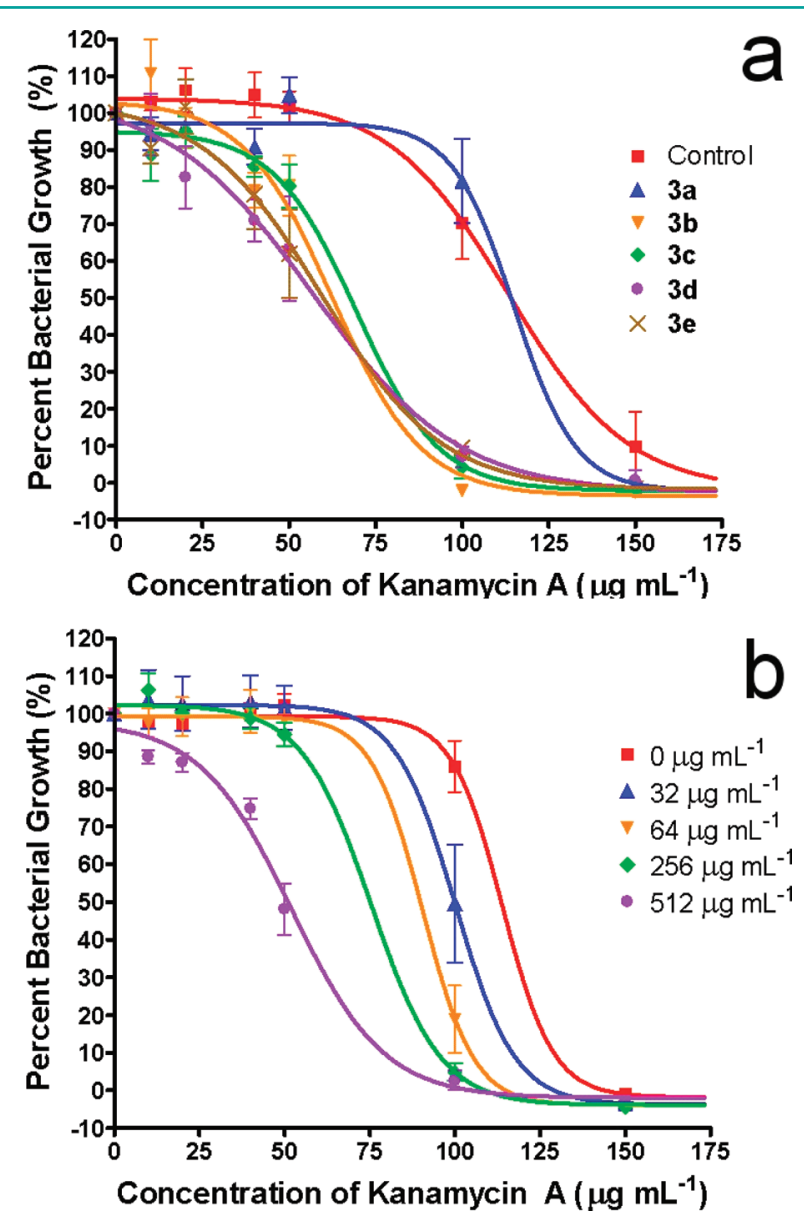

Figure 4. Results from checkerboard assays performed with a resistant strain of E. faecium expressing AAC $\left(6^{\prime}\right)$-Ii. (a) Potentiation effect of compounds $3 \mathrm{a}-\mathrm{e}\left(512 \mu \mathrm{g} \mathrm{mL}^{-1}\right)$ on the antibacterial activity of kanamycin A. (b) Dose-dependent potentiation effect of compound 3c on the antibacterial activity of kanamycin A. The data was fitted with a sigmoidal dose-response (variable slope) equation. All data points are from quadruplicate experiments.

data, addition of $3 \mathbf{a}$ has a negligible effect on the $\mathrm{MIC}_{50}$ of kanamycin $\mathrm{A}$. Compounds $\mathbf{3 b}-\mathbf{e}$ on the other hand decrease the $\mathrm{MIC}_{50}$ of kanamycin A considerably, with $\mathbf{3 d}$ and $\mathbf{3 e}$ causing the $\mathrm{MIC}_{50}$ to drop by half. The potentiation effects observed here for $\mathbf{3 b}-\mathbf{e}$ are much superior to that previously reported for compound $1 .^{11}$ It is noteworthy that for each of $\mathbf{3 b}-\mathbf{e}$, a dose-dependent behavior is observed, as exemplified for 3c (Figure 4, panel b). Finally, LC-MS analysis of the cellular mixture obtained when exposing E. faecium lysate to $\mathbf{3 d}$ shows a peak corresponding to bisubstrate $\mathbf{2 d}$, which is absent in the negative control (see Supporting Information).

Aminoglycosides were the first antibacterial agents effective against tuberculosis and many Gram-negative pathogens. As with other antibiotics, bacterial resistance to aminoglycosides is threatening their clinical use. One demonstrated strategy to overcome antibiotic resistance is to design inhibitors of the most common mechanisms of resistance. Numerous resistance mechanisms have been reported for penicillins (efflux, decreased cell permeability, and expression of various $\beta$ lactamases), yet the combination of amoxicillin with the $\beta$ lactamase inhibitor clavulinate has generated sales of more than a billion dollars in one year only. ${ }^{24}$ Expression of AAC $\left(6^{\prime}\right)$ enzymes is one of the most common determinants of aminoglycoside resistance in the clinics. We have previously reported that aminoglycoside-CoA bisubstrates are potent AAC $\left(6^{\prime}\right)$ inhibitors. ${ }^{7}$ Although these were useful molecules to interrogate enzyme behavior, their use is limited by their inability to penetrate cells membranes. On the other hand, a truncated bisubstrate inhibitor, compound $\mathbf{1}$, was found to block resistance in cells, yet its potentiation effect on the antibacterial activity of kanamycin A was modest. We report here a new strategy to improve the potency while maintaining cell-permeability of aminoglycoside resistance inhibitors. Taking advantage of the promiscuity of the CoA biosynthetic pathway, we have designed cell-permeable molecules that are extended to potent bisubstrate inhibitors in cells.

In summary, compounds with longer linkers (e.g., $\mathbf{3 d}$ and $\mathbf{3 e}$ ) are better substrates of PanK in vitro and also better potentiators of the antibacterial activity of kanamycin A in $E$. faecium. Interestingly, this is opposite to the trend observed for in vitro $\mathrm{AAC}\left(6^{\prime}\right)$ inhibition by the corresponding bisubstrates $\mathbf{2 a}-\mathbf{e}$. Since none of $\mathbf{3 a}-\mathbf{e}$ show intrinsic antibacterial activity of their own, we attribute the trend observed in cells to the ratelimiting role of prodrug activation. Although compounds with longer linkers (e.g., $2 \mathrm{c}-\mathrm{e}$ ) are poorer $\mathrm{AAC}\left(6^{\prime}\right)$ inhibitors, their formation from the corresponding prodrugs $3 \mathrm{c}-\mathbf{e}$ in vivo is likely more efficient as suggested by the in vitro biosynthetic studies (Figure 3, panel c, IV, V, and VI). Figure 2 shows the proposed activation path of $3 \mathbf{a}-\mathbf{e}$ and explains how the antibacterial activity of kanamycin is rescued by these molecules. Of note is that our previous studies with AAC $\left(6^{\prime}\right)$ $\mathrm{Ii}^{11}$ suggest that intermediates $\mathbf{6 b}-\mathbf{e}$ and $7 \mathbf{b}-\mathbf{e}$ may also inhibit the enzyme to some extent. To our knowledge, compounds $3 \mathbf{b}-\mathbf{e}$ show the largest potentiation effect reported to date for the antibacterial activity of kanamycin A against a bacterial strain resistant to aminoglycosides. This work presents a new approach for generating molecules that resensitize bacteria to aminoglycoside antibiotics. Moreover, it is envisioned that the prodrug activation strategy used here has the potential to find use with other biologically active CoA derivatives.

\section{METHODS}

Synthesis. General Procedure for Synthesis of Compounds $3 a-e$. Neamine free base $(145 \mathrm{mg}, 0.45 \mathrm{mmol})$ was dissolved in water $(3 \mathrm{~mL})$, and the corresponding NBD ester $(\mathbf{5 a}-\mathbf{e}, 0.23 \mathrm{mmol})$ was dissolved in acetone $(2 \mathrm{~mL})$. The two solutions were mixed and stirred for $10 \mathrm{~min}(\mathbf{5 a})$ or $20 \mathrm{~min}(\mathbf{5 b}-\mathbf{e})$. In another vial, D-pantethine $(66$ $\mathrm{mg}, 0.12 \mathrm{mmol})$, DIPEA ( $1 \mathrm{~mL}, 5.7 \mathrm{mmol})$, and DTT $(20 \mathrm{mg}, 0.13$ $\mathrm{mmol})$ were mixed in acetone $(2 \mathrm{~mL})$ and sonicated until a homogeneous mixture is obtained. This solution was then transferred to the neamine/NBD ester reaction mixture and then allowed to stir overnight. The solvent was evaporated under vacuum, and the residue was dissolved in water $(10 \mathrm{~mL})$. TFA was added to $\mathrm{pH} \sim 3$, which was then followed by three successive ethyl acetate washes. The aqueous layer was evaporated to dryness by lyophilization. HPLC purification was achieved through method 3 followed by method 4 (see Supporting Information). Compounds $\mathbf{3 a}-\mathbf{e}$ all appear as white fluffy powders after lyophilization (yields $20-50 \%$ ).

General Procedure for Synthesis of Compounds $5 a-e$ from Carboxylic Acids 4a-e. endo- $N$-Hydroxy-5-nornornene-2,3-dicarboximide (NBD) (1.07 g, $6 \mathrm{mmol}$ ) and the corresponding carboxylic acid 
$(6 \mathrm{mmol}, 4 \mathrm{a}-\mathbf{e})$ were dissolved in dichloromethane $(50 \mathrm{~mL})$. DCC $(1.24 \mathrm{~g}, 6 \mathrm{mmol})$ was added to the mixture, followed by a catalytic amount of DMAP $(\sim 20 \mathrm{mg})$. A few minutes after addition of DCC, a white solid (DCU) precipitated out. The reaction was stirred at RT overnight. The presence of the desired NBD ester (5a-e) was monitored by TLC ( $1: 1$ ethyl acetate/hexanes, $\left.R_{f}=0.45-0.50\right)$. The solid DCU was removed by filtration and the filtrate was evaporated to approximately $1 \mathrm{~mL}$. Flash column chromatography (ethyl acetate/ hexanes 1:2) was used to purify the desired compounds, which typically appeared as white, flakey solids upon evaporation of all solvents (yields 64-82\%).

Biological Assays. $A A C\left(6^{\prime}\right)$-li Inhibition Assay. AAC $\left(6^{\prime}\right)$-Ii was expressed and purified as previously described. ${ }^{7}$ The AAC $\left(6^{\prime}\right)$-Ii inhibition assay was conducted with a BioLogic SFM 400 stopped-flow mixing chamber controlled by an MPS-60 unit. The data was collected on a MOS $250 \mathrm{UV}-\mathrm{Vis}$ spectrophotometer at $412 \mathrm{~nm}$. The TC-100 cuvette used had an observation path length of $1 \mathrm{~cm}$. Data was processed with Biokine32 ver 4.2 (BioLogic) to determine initial rates, which were next fitted in GraphPad Prism 4.0 to determine kinetic parameters. The total reaction volume was $440 \mu \mathrm{L}$, from 4 reagentcontaining chambers each containing an equal volume of $110 \mu \mathrm{L}$. Measurements were taken at a wavelength of $412 \mathrm{~nm}$. All solutions were in MES Buffer $(25 \mathrm{mM}, \mathrm{pH} 6.0)$. The kinetic activity of AAC $\left(6^{\prime}\right)$ Ii was first determined with varying concentrations of $\mathrm{AcCoA}$ and a fixed concentration of neamine, using the following solutions in 4 separate chambers: (1) MES buffer solution (25 mM); (2) various concentrations of $\mathrm{AcCoA}(50,100,150$, and $200 \mu \mathrm{M})$; (3) neamine $(1.6 \mathrm{mM})$ and DTNB $(4 \mathrm{mM})$; and $(4) \mathrm{AAC}\left(6^{\prime}\right)-\mathrm{Ii}(4 \mu \mathrm{M})$. The enzymatic activity of $\mathrm{AAC}\left(6^{\prime}\right)$-Ii was next determined in the presence of the molecules of interest to measure inhibition constants $\left(K_{\mathrm{i}}\right)$. To this end, the following solutions were separated in the instrument into 4 chambers: (1) MES buffer solution (25 mM); (2) varying concentrations of inhibitor $(1,2,4$, and $8 \mu \mathrm{M})$ mixed with various concentrations of $\mathrm{AcCoA}(50,100,150$, and $200 \mu \mathrm{M})$; (3) neamine $(1.6 \mathrm{mM})$ and DTNB $(4 \mathrm{mM})$; and $(4) \mathrm{AAC}\left(6^{\prime}\right)-\mathrm{Ii}(4 \mu \mathrm{M})$. All data points are from triplicate experiments.

PanK Enzyme Assay. The E. coli pantothenate kinase (PanK or coaA enzyme) was expressed and purified as previously described. ${ }^{25}$ Enzyme activity was measured as described in the literature. ${ }^{16}$ This assay couples the production of ADP to the consumption of $\mathrm{NADH}$ through the activity of pyruvate kinase and lactic dehydrogenase. The decrease of NADH concentration was monitored at $340 \mathrm{~nm}$. Reactions were performed at $25^{\circ} \mathrm{C}$ in an Agilent $8453 \mathrm{UV}-\mathrm{Vis}$ spectrophotometer coupled to an Agilent 89090A Peltier temperature controller. Kinetic parameters were determined by fitting the rate data into the Michaelis-Menten equation using GraphPad Prism 4.0. Each reaction mixture $(500 \mu \mathrm{L})$ contained ATP $(1.5 \mathrm{mM}), \mathrm{NADH}(0.3 \mathrm{mM})$, phosphoenolpyruvate $(0.5 \mathrm{mM}), \mathrm{MgCl}_{2}(10 \mathrm{mM}), \mathrm{KCl}(20 \mathrm{mM})$, pyruvate kinase (5 units), lactic dehydrogenase (5 units), and PanK (5 $\mu \mathrm{g}, 278 \mathrm{nM})$ in Tris-HCl buffer $(50 \mathrm{mM}, \mathrm{pH} 7.6)$. The reaction was initiated by addition of the desired substrate $(10-160 \mu \mathrm{M})$. All data points are from triplicate experiments.

Biosynthetic in Vitro Assay with a Mixture of PanK, PPAT, and DPCK Enzymes. The E. coli enzymes pantothenate kinase (PanK or coaA enzyme), phosphopantetheine adenylyltransferase (PPAT or coaD enzyme), and dephosphocoenzyme A kinase (DPCK or coaE enzyme) were expressed and purified as previously described. ${ }^{25}$ Each reaction mixture $(500 \mu \mathrm{L})$ contained ATP $(5.0 \mathrm{mM}), \mathrm{KCl}(20 \mathrm{mM})$, $\operatorname{MgCl}_{2}(10 \mathrm{mM})$, DTT $(2.0 \mathrm{mM})$, PanK (5 $\left.\mu \mathrm{g}, 278 \mathrm{nM}\right)$, PPAT (5 $\mu \mathrm{g}$, $500 \mathrm{nM})$, and DPCK $(5 \mu \mathrm{g}, 454 \mathrm{nM})$ in Tris-Cl Buffer $(50 \mathrm{mM}, \mathrm{pH}$ 7.6). The reaction was initiated with the addition of pantetheine (5.0 $\mathrm{mM}$ ) for comparison, water as a negative control, or compounds $3 \mathrm{a}-\mathbf{e}$ $(5.0 \mathrm{mM})$. Reactions were incubated for $3 \mathrm{~h}$ at $\mathrm{RT}$ and then stopped by heating the mixture to $95{ }^{\circ} \mathrm{C}$ for $5 \mathrm{~min}$. The precipitated protein was removed by centrifugation (13,000 rpm for $5 \mathrm{~min}$ ), and the supernatant was analyzed by LC-MS. Reversed-phase analytical HPLC was performed with an analytical $4.60 \times 250 \mathrm{~mm}$, SYNERGI 4 $\mu \mathrm{m}$ Hydro-RP 80A (Phenomenex) column coupled to an Agilent 6120 Quadrupole LC-MS system for ESI-MS analysis. The HPLC conditions had the sample eluted at a flow rate of $0.5 \mathrm{~mL} \mathrm{~min}{ }^{-1}$ using a combination of mobile phase $\mathrm{A}\left(\mathrm{H}_{2} \mathrm{O}\right)$ and mobile phase $\mathrm{B}$ (acetonitrile). Elution conditions are as follows: isocratic $1 \%$ phase $\mathrm{B}$ from 0 to $3 \mathrm{~min}$; followed by the following linear gradients of phase B: $1-10 \%$ from $3-5 \mathrm{~min} ; 10-15 \%$ from $5-10 \mathrm{~min} ; 15-30 \%$ from $10-$ $13 \mathrm{~min}$; and finally isocratic phase B at $30 \%$ from $13-26 \mathrm{~min}$. The detector was set to $214 \mathrm{~nm}$. These experiments were run in duplicates.

Checkerboard Assay To Determine the Potentiation Effect of Compounds 3a-e on the Antibacterial Activity of Kanamycin A on a Resistant Strain. A two-dimensional checkerboard MIC assay was carried out as previously described ${ }^{11}$ to observe the potentiation activity of compounds $3 \mathbf{a}-\mathbf{e}$ toward the antibacterial activity of kanamycin A against Enterococcus faecium ATCC 19434 that expresses AAC $\left(6^{\prime}\right)$-Ii. Compounds $3 \mathrm{a}-\mathrm{e}$ were diluted by 2 -fold sequential dilutions to create a gradient from 32 to $512 \mu \mathrm{g} \mathrm{mL}$. The concentrations used for kanamycin A were $0,10,20,40,50,100,150$, 200,250 , and $300 \mu \mathrm{g} \mathrm{mL}^{-1}$. The cultures were grown at $37^{\circ} \mathrm{C}$ for $16 \mathrm{~h}$ in 96-well plates, and then monitored for optical density at $600 \mathrm{~nm}$ using a Spectramax 190 microplate reader (Molecular Devices). Data was normalized against a positive growth control and reported as a percentage of bacterial cell growth. All data points are from quadruplicate experiments.

\section{ASSOCIATED CONTENT}

\section{Supporting Information}

Detailed descriptions of experimental procedures, characterization of all compounds as well as selected HPLC traces and NMR spectra. This material is available free of charge via the Internet at http://pubs.acs.org.

\section{AUTHOR INFORMATION}

\section{Corresponding Author}

*E-mail: karine.auclair@mcgill.ca.

\section{ACKNOWLEDGMENTS}

This work was supported by research grants from the Canadian Institute of Health Research (CIHR) and the National Science and Engineering Research Council of Canada (NSERC) to K.A. K.V. was supported by the CIHR Strategic Training Initiative in Chemical Biology and Fonds québécois de la recherche sur la nature et les technologies (FQRNT) scholarships. The authors are grateful to G. D. Wright at McMaster University for sharing his AAC(6')-Ii, PanK, PPAT, and DPCK expression plasmids.

\section{REFERENCES}

(1) Wright, G. D., Berghuis, A. M., Mobashery, S. (1998) Aminoglycoside Antibiotics: Structures, Functions, and Resistance, in Resolving the Antibiotic Paradox (Rosen, B. P., Mobashery, S., Ed.), pp 27-69, Kluwer Academic/Plenum, New York.

(2) Vakulenko, S. B., and Mobashery, S. (2003) Versatility of aminoglycosides and prospects for their future. Clin. Microbiol. Rev. 16, 430-450.

(3) Kotra, L. P., Haddad, J., and Mobashery, S. (2000) Aminoglycosides: perspectives on mechanisms of action and resistance and strategies to counter resistance. Antimicrob. Agents Chemother. 44, $3249-3256$.

(4) Davies, J., and Wright, G. D. (1997) Bacterial resistance to aminoglycoside antibiotics. Trends Microbiol. 5, 234-240.

(5) Wright, G. D. (1999) Aminoglycoside-modifying enzymes. Curr. Opin. Microbiol. 2, 499-503.

(6) Shakya, T., Wright, G. D. (2007) Mechanisms of Aminoglycoside Antibiotic Resistance, in Aminoglycoside Antibiotics: From Chemical Biology to Drug Discovery (Arya, D. P., Ed.), pp 119-140, John Wiley \& Sons, Inc., New Jersey.

(7) Gao, F., Yan, X., Baettig, O. M., Berghuis, A. M., and Auclair, K. (2005) Regio- and chemoselective 6'-N-derivatization of amino- 
glycosides: Bisubstrate inhibitors as probes to study aminoglycoside 6'N-acetyltransferase. Angew. Chem., Int. Ed. 44, 6859-6862.

(8) Gao, F., Yan, X., Zahr, O., Larsen, A., Vong, K., and Auclair, K. (2008) Synthesis and use of sulfonamide-, sulfoxide-, or sulfonecontaining aminoglycoside-CoA bisubstrates as mechanistic probes for aminoglycoside N-6'-acetyltransferase. Bioorg. Med. Chem. Lett. 18, $5518-5522$.

(9) Gao, F., Yan, X., and Auclair, K. (2009) Synthesis of a phosphonate-linked aminoglycoside-coenzyme A bisubstrate and use in mechanistic studies of an enzyme involved in aminoglycoside resistance. Chem.-Eur. J. 15, 2064-2070.

(10) Magalhaes, M. L. B., Vetting, M. W., Gao, F., Freiburger, L., Auclair, K., and Blanchard, J. S. (2008) Kinetic and structural analysis of bisubstrate inhibition of the Salmonella enterica aminoglycoside 6'$\mathrm{N}$-acetyltransferase. Biochemistry 47, 579-584.

(11) Gao, F., Yan, X., Shakya, T., Baettig, O. M., Ait-Mohand-Brunet, S., Berghuis, A. M., Wright, G. D., and Auclair, K. (2006) Synthesis and structure-activity relationships of truncated bisubstrate inhibitors of aminoglycoside 6'-N-acetyltransferases. J. Med. Chem. 49, 52735281.

(12) Mishra, P. K., and Drueckhammer, D. G. (2000) Coenzyme A analogues and derivatives: Synthesis and applications as mechanistic probes of coenzyme A ester-utilizing enzymes. Chem. Rev. 100, 32833309.

(13) Begley, T. P., Kinsland, C., and Strauss, E. (2001) The biosynthesis of coenzyme A in bacteria. Vitam. Horm. 61, 157-171.

(14) Vallari, D. S., and Rock, C. O. (1985) Pantothenate transport in Escherichia coli. J. Bacteriol. 162, 1156-1161.

(15) Jackowski, S., and Rock, C. O. (1984) Metabolism of 4'phosphopantetheine in Escherichia coli. J. Bacteriol. 158, 115-120.

(16) Strauss, E., and Begley, T. P. (2002) The antibiotic activity of Npentylpantothenamide results from its conversion to ethyldethiacoenzyme A, a coenzyme A antimetabolite. J. Biol. Chem. 277, 4820548209.

(17) Meier, J. L., Mercer, A. C., Rivera, H. Jr., and Burkart, M. D. (2006) Synthesis and evaluation of bioorthogonal pantetheine analogues for in vivo protein modification. J. Am. Chem. Soc. 128, 12174-12184.

(18) Clarke, K. M., Mercer, A. C., La Clair, J. J., and Burkart, M. D. (2005) In vivo reporter labeling of proteins via metabolic delivery of coenzyme A analogues. J. Am. Chem. Soc. 127, 11234-11235.

(19) Song, W. J., and Jackowski, S. (1992) Cloning, sequencing, and expression of the pantothenate kinase (coaA) gene of Escherichia coli. J. Bacteriol. 174, 6411-6417.

(20) Geerlof, A., Lewendon, A., and Shaw, W. V. (1999) Purification and characterization of phosphopantetheine adenylyltransferase from Escherichia coli. J. Biol. Chem. 274, 27105-27111.

(21) Mishra, P. K., Park, P. K., and Drueckhammer, D. G. (2001) Identification of yacE (coaE) as the structural gene for dephosphocoenzyme A kinase in Escherichia coli K-12. J. Bacteriol. 183, 27742778.

(22) Murray, B. E. (1990) The life and times of the Enterococcus. Clin. Microbiol. Rev. 3, 46-65.

(23) Jackowski, S., and Rock, C. O. (1981) Regulation of coenzyme A biosynthesis. J. Bacteriol. 148, 926-932.

(24) Davies, J., and Davies, D. (2010) Origins and evolution of antibiotic resistance. Microbiol. Mol. Biol. Rev. 74, 417-433.

(25) Nazi, I., Koteva, K. P., and Wright, G. D. (2004) One-pot chemoenzymatic preparation of coenzyme A analogues. Anal. Biochem. $324,100-105$.

(26) Worthington, A. S., and Burkart, M. D. (2006) One-pot chemoenzymatic synthesis of reporter-modified proteins. Org. Biomol. Chem. 4, 44-46. 